\title{
UMOWA RAMOWA MIĘDZY STOLICĄ APOSTOLSKĄ I REPUBLIKĄ BURUNDI W SPRAWACH WSPÓLNEGO INTERESU Z 6 LISTOPADA 2012 ROKU NARZĘDZIEM INKULTURACJI NA KONTYNENCIE AFRYKAŃSKIM
}

\section{WSTĘP}

Aktywność Stolicy Apostolskiej w sferze umów zawieranych z państwami, od pewnego czasu wyraźnie kieruje się ku Południu świata, w szczególności zaś ku Afryce. Specjalnego znaczenia nabrał tutaj termin ,inkulturacja”, intuicyjnie użyty po raz pierwszy przez Jana Pawła II w 1979 r. w odniesieniu do ewangelizacji w trzecim tysiącleciu 1 .

W Adhortacji apostolskiej Ecclesia in Africa z 14 września 1995 r. wymieniony Ojciec Święty pisał: „Ojcowie Synodalni często podkreślali, że szczególnie ważną rolę w dziele głoszenia Ewangelii odgrywa inkulturacja, to znaczy proces, poprzez który katecheza wciela się [podkreśl. w tekście - W.G.] w różne kultury. Inkulturacja ma dwa wymiary: $\mathrm{z}$ jednej strony oznacza wewnętrzne przekształcenie autentycznych wartości kulturowych przez ich integrację w chrześcijaństwie, z drugiej strony jest zakorzenianiem chrześcijaństwa w różnych kulturach. Według Synodu inkulturacja jest $[\ldots]$ jednym z największych wyzwań, jakie stoją przed Kościołem na kontynencie u progu trzeciego tysiąclecia [...] Biskupom i Konferencjom Episkopatów Synod przypomina, że inkulturacja obejmuje wszystkie dziedziny życia Kościoła i ewangelizacji: teologię, liturgię, życie i strukturę Kościoła"2.

Ks. prof. dr hab. WojCiech GóRALSKI - Wydział Prawa Kanonicznego, Uniwersytet Kardynała Stefana Wyszyńskiego w Warszawie, ul. Dewajtis 5, 01-815 Warszawa; e-mail: w_goralski@wp.pl; https://orcid.org/0000-0001-6548-4120

${ }^{1}$ IoAnnes PAulus PP. II, Adhortatio apostolica Catechesi tradendae (16.10.1979), AAS 71 (1979), s. 1277-1340, nr 35.

${ }^{2}$ Tenże, Adhortatio apostolica Ecclesia in Africa (14.09.1995), AAS 88 (1996), s. 5-82, nr 59. 
Jednym z narzędzi inkulturacji na kontynencie afrykańskim jest umowa zawierana między Stolicą Apostolską i danym państwem. Wynegocjowane bowiem uzgodnienia dwustronne ,przekładają się” - w znacznej mierze - na relację zharmonizowania, bynajmniej mechanicznego, wiary i kultury. Sakralność, która przenika kulturę afrykańską w każdym swoim aspekcie, zarówno socjo-antropologicznym, jak i normatywnym, wytycza inkulturacji intensywność i granice 3 .

W dość długi już ciąg umów zawieranych po Soborze Watykańskim II przez Stolicę Apostolską z państwami afrykańskimi wpisała się umowa ramowa (Accord-cadre) w sprawach wspólnego interesu (sur matières d'intérêt commun) zawarta 6 listopada 2012 r. z Republiką Burundi. To wschodnio-afrykańskie państwo, które - jak już wspomniano - uzyskało niepodległość dopiero w 1962 r., sąsiadujące z Demokratyczną Republiką Konga, Tanzanią i Ruandą, liczące niespełna osiem milionów mieszkańców, w którym katolicy stanowią niespełna 61\% ludności (pozostali to animiści, protestanci i muzułmanie), zamieszkuje lud Hutu (85\% populacji) oraz plemiona Tutsi i Pigmeje. Burundi ma ustrój republikański, o systemie wielopartyjnym; głową państwa jest prezydent, władza ustawodawcza należy do dwuizbowego parlamentu, a władzę wykonawczą (poza prezydentem) sprawuje rząd, powoływany przez prezydenta, z premierem na czele ${ }^{4}$.

${ }^{3}$ F. VECCHI, Il concordato del 2012 tra la Santa Sede e la Repubblica del Burundi alla prova di un 'inculturazione che precede il dirito alla libertà religiosa, „Ius Ecclesiae” 30 (2018), nr 2, s. 572.

${ }^{4}$ Burundi - jako jeden z nielicznych krajów Afryki - uzyskał państwowość przed okresem kolonizacji. Najprawdopodobniej od XVII w. panowała tu dynastia z plemienia Tutsi, a jej królestwo zwane Urundi posiadało m.in. jednolity język rundi i bogatą literaturę ustną. W latach 1896-1897 królestwo uległo ekspansji niemieckiej, a w 1903 r. zostało włączone do Niemieckiego Królestwa Afryki Równikowej. W 1916 r. Urundi zajęły wojska belgijskie, a od 1923 r. utworzono belgijskie terytorium mandatowe pod nazwą Rwanda-Urundi; nastąpiło wówczas podtrzymanie dominacji mniejszości etnicznej Tutsi nad Hutu.

W 1959 r. Burundia uzyskała autonomię, a w 1962 r. niepodległość (jako królestwo pod rządami Mwambutsy IV). W 1966 r. ppłk M. Nicombero (Tutsi) przeprowadził wojskowy zamach stanu i ustanowił republikę. W 1972 r., trwające od dawna waśnie etniczne przerodziły się w powstanie Hutu, wówczas to w Bujumburze doszło do masowych mordów Tutsi. Wzajemne masakry pociągnęły za sobą liczne ofiary.

Od 1989 r. podejmowano próby uśmierzenia napięć etnicznych. W 1992 r. miało miejsce referendum, przyjęto wówczas nową konstytucję, wprowadzono wielopartyjny systemu rządów (z zakazem działalności partii etnicznych). W 1993 r. wybory prezydenckie wygrał po raz pierwszy kandydat Hutu (M. Ndadaye), wkrótce zamordowany, co wywołało nową falę walk (pochłonęły ok. 50 tys. ofiar).

W 1996 r., po wojskowym zamachu stanu, władzę w kraju objął płk Pierre Buyoya (z plemienia Tutsi). Niezadowolenie Hutu doprowadziło do wznowienia walk plemiennych, kiedy to wojna domowa dotknęła również Tanzanię, Kongo (dawny Zair), Ugandę, a pośrednio także Angolę, Kongo Brazzaville i Republikę Środkowoafrykańską.

Próby mediacji podjął najpierw tanzański polityk Julius Nyerere (1998). a następnie Nelson Mandela (1999); w ich wyniku, w 2000 r. w Arushy (Tanzania), podpisane zostało przez Buyoyę i przedstawicieli kilku burundyjskich ugrupowań (w obecności N. Mandeli i B. Clintona) porozumie- 
Struktura administracyjna Kościoła katolickiego w Burundi obejmuje dwie prowincje kościelne: bujumburską (archidiecezja bujumburska, diecezja Bubanza, diecezja Bururi) i gitegańską (archidiecezja gitegańska, diecezja Muyinga, diecezja Ngozi, diecezja Rutana, diecezja Ruyigi) ${ }^{5}$.

Umowa ramowa w sprawach wspólnego interesu, podpisana w Bujumburze przez abp. Franco Coppolę, nuncjusza apostolskiego w Burundi (w imieniu Stolicy Apostolskiej) i Laurenta Kavakure, ministra Relacji Zewnętrznych i Współpracy Międzynarodowej (w imieniu Republiki Burundi), zmodyfikowana wzajemnymi notami 5 lipca 2012 r., została ratyfikowana 29 stycznia 2014 r. $^{6}$

Traktat, obejmujący preambułę, 22 artykuły oraz aneks, reguluje szeroki wachlarz spraw interesujących obydwie strony; stanowi znaczący, jak się wydaje, instrument służący wzajemnemu, obustronnie wzbogacającemu dialogowi kultury z wiarą ${ }^{7}$.

nie pokojowe, przewidujące m.in. utworzenie wieloetnicznego rządu oraz powołanie tymczasowego parlamentu. W myśl uzgodnień z 2001 r., przez najbliższe półtora roku miał rządzić nadal P. Buyoi, a następnie, przez taki sam okres, przedstawiciel Hutu: wiceprezydent Domitien Ndayizeye. Nadzór nad uspokojeniem sytuacji objęły siły pokojowe RPA, Nigerii, Senegalu i Ghany, a porozumienia nie zaakceptowały dwa największe ugrupowania Hutu: Siły Obrony Demokracji (FDD) i Siły Wyzwolenia Narodowego (FLN), które wznowiły toczące się od ośmiu lat walki (do końca 2002 r. zginęło ponad 250 tys. ludzi).

W 2003 r., zgodnie z porozumieniami, nastąpiło przekazanie władzy przez P. Buyoya (Tutsi) swemu zastępcy D. Ndayizeye (Hutu). Z kolei w 2004 r. w Gatumbie (opodal Bujumbury) miejscowi Hutu z FNL dokonali kolejnej masakry kilku tysięcy Tutsi pochodzących z sąsiedniej Demokratycznej Republiki Konga, przebywających w obozie dla uchodźców. W lipcu 2005 r. nastąpiło zawieszenie broni i przeprowadzenie demokratycznych wyborów. Ostatnie rebelianckie ugrupowanie złożyło jednak broń dopiero w kwietniu $2009 \mathrm{r}$.

Pod koniec grudnia 2018 r. prezydent Burundi zadecydował o przeniesieniu stolicy kraju z Bujumbury do znajdującego się o ok. 100 km na wschód miasta Gitega. Decyzja została zaakceptowana przez parlament, natomiast jej całkowite wdrożenie w życie ma zająć 3 lata. Obecnie siedziba rządu oraz parlamentu w dalszym ciągu znajduje się w Bujumburze. Zob. M. Budzisz, Burundi, [w:] Encyklopedia Katolicka, t. II, Lublin: Towarzystwo Naukowe KUL 1976, s. 1230-1231; Burundi, [w:] Encyklopedia Gazety Wyborczej, t. III, Kraków [b.r.w.], s. 51-52; Republika Burundi, [w:] https://encyklopedia.interia.pl/geografia-nauki-pokrewne/panstwa/news-burundi,nId,2010934\#utm source=paste\&utm_medium=paste\&utm_campaign=other [dostęp: 19.03.2020].

${ }^{5}$ W 1912 r. Pius X erygował wikariat apostolski w Kivu oraz wikariat apostolski w Nijanzy południowej (łączyła Ruandę, Burundi i Buhę). W 1922 r. z podziału wikariatu Kivu powstały wikariaty apostolskie w Ruandzie i Burundi. Ten ostatni został w 1949 r. podzielony na wikariaty Gitedze i Negozi, do którego dołączono w 1959 r. Bujumburę. Następnie wszystkie wikariaty podniesiono do rangi diecezji. Zob. Annuario Pontificio, Città del Vaticano: Libreria Editrice Vaticano 2006, s. 1122.

${ }^{6}$ Accord-Cadre entre le Saint-Siège et la République du Burundi sur matières d'intérêt commun (6.11.2012), AAS 106 (2014), s. 195-207.

${ }^{7}$ Zob. A. HalembA, Zagadnienie inkulturacji w Afryce w okresie powstania Orędzia ,Africae terrarum” Pawła VI, „Śląskie Studia Historyczno-Teologiczne” 25-26 (1992-1993), s. 69-98. 


\section{PREAMBUŁA}

Preambuła umowy, obejmująca siedem akapitów, wskazuje cel, przesłanki i okoliczności jej zawarcia.

W akapicie pierwszym, określającym cel zawartej umowy, układające się strony wyrażają troskę o harmonijne współdziałanie na rzecz ludności burundyjskiej oraz pragnienie określenia ram prawnych relacji między Kościołem katolickim i Państwem burundyjskim ${ }^{8}$.

Akapit drugi wskazuje podstawy prawne, które każda ze stron uwzględniła zawierając umowę. Tak więc ze strony Państwa burundyjskiego wzięto po uwagę obowiązujące normy konstytucyjne ${ }^{9}$, natomiast Stolica Apostolska powołała się na dokumenty Soboru Watykańskiego II oraz normy prawa kanonicznego ${ }^{10}$.

W akapicie trzecim, mającym charakter socjologiczny, stwierdzono, iż znaczna większość burundyjczyków należy do Kościoła katolickiego, który ma znaczenie i odgrywa swoją rolę w życiu narodu burundyjskiego służąc rozwojowi duchowemu, moralnemu, społecznemu, kulturowemu i materialnemu tegoż ludu ${ }^{11}$.

Akapit czwarty zawiera przesłankę również natury socjologicznej, dotyczącą faktu intensywności rozszerzenia się Kościoła katolickiego na całym terytorium narodowym oraz siły więzów, które je (Kościół i terytorium) jednoczą i kontrolują, jak również kwalifikacji i oddania duszpasterzy, gwarantowanego rygorystycznymi wymogami norm kanonicznych i organizacją hierarchiczną ${ }^{12}$.

W akapicie piątym przywołano uznaną zasadę międzynarodową o wolności religijnej; jest to więc przesłanka o charakterze prawnym ${ }^{13}$.

${ }^{8}$ „Le Saint-Siège et la République du Burundi, soucieux d'une collaboration harmonieuse au bénéfice de la population burundaise et désireux de fixer le cadre juridique des relations entre l'Eglise catholique et l'Etat burundais". Accord-Cadre entre le Saint-Siège et la République du Burundi, Preambuta.

${ }^{9} \mathrm{~W}$ momencie zwierania umowy w Republice Burundi obowiązywała konstytucja z 18 marca 2005 r., zob. Constitution du Burundi (18.03.2005), [w:] https://ww.refwordl.org/docid/2c2df0942HTML [dostęp: 21.03.2020].

10 ,en référence, pour l'Etat burundais, aux normes constitutionnelles en vigueur et, pour le Saint-Siège, aux documents du Concile CEcuménique Vatican II et aux normes du droit canonique". Accord-Cadre entre le Saint-Siège et la République du Burundi.

${ }^{11}$ „tenant compte du fait qu'une grande majorité de burundais appartient àl'Eglise catholique, ainsi que de l'importance et du rôle que continue de jouer l'Eglise catholique dans la vie de la nation burundaise au service du développement spirituel, moral, social, culturel et matériel du peuple burundais". Tamże.

12 „eu égard à la densité des implantations de l'Eglise catholique sur tout le territoire national et à la force des réseaux qui les unissent et les contrôlent, ainsi qu'à la qualification et au dévouement de ses agents pastoraux garantis par les exigences rigoureuses des normes canoniques et de l'organisation hiérarchique". Tamże.

13 „rappelant le principe internationalement reconnu de liberté religieuse”. Tamże. 
Treścią akapitu szóstego, noszącego na sobie znamię historyczne, jest uznanie dziejów Kościoła katolickiego i jego implementacji w Burundi, wraz z utworzeniem pierwszych misji (Muyaga, Megera, Buhonga, Kanyinya i Rugari) w latach $1898-1909^{14}$.

Uznanie dobrych relacji istniejących między Państwem Burundi i Stolicą Apostolską od czasu ustanowienia Nuncjatury Apostolskiej w Bujumburze (16 grudnia 1962 r.) stanowi przedmiot akapitu siódmego (o charakterze socjologiczno-historycznym) $)^{15}$.

\section{REGULACJE UMOWY}

Uzgodnienia zawarte w Umowie ramowej, zawarte w 22 artykułach, dotyczą różnorodnych spraw interesujących obie strony. Wymienione jednostki redakcyjne można podzielić tematycznie następująco: zasady ogólne (art. 1-5), sprawowanie kultu Bożego (art. 6), nominacje kościelne (art. 7), przestępstwa duchownych i osób zakonnych oraz sekrety: spowiedzi i zawodowy (art. 8), dobra materialne kościelnych osób prawnych oraz duchownych (art. 9, 11 i 18), budownictwo sakralne i kościelne (art. 10), posługiwanie się przez Kościół środkami przekazu (art. 12), małżeństwo (art. 13), zrzeszanie się wiernych (art. 14), prowadzenie przez Kościół placówek oświatowych i wychowawczych (art. 15), prowadzenie przez Kościół instytucji dobroczynnych (art. 16), udział finansowy Państwa w działalności Kościoła na rzecz narodu (art. 17), opieka duszpasterska nad zaangażowanymi w Siłach zbrojnych i w Siłach bezpieczeństwa oraz nad przebywającymi w zakładach i instytutach zamkniętych (art. 19), postanowienia końcowe (art. 20-22).

\subsection{ZASADY OGÓLNE (ART. 1-5)}

Wśród zasad ogólnych uzgodnionych w umowie znalazło się pięć artykułów poświęconych kwestiom o znaczeniu podstawowym, których uregulowania stanowią podstawę dla regulacji szczegółowych.

Tak więc w art. 1 „Stolica Apostolska i Republika Burundi potwierdzają, że Kościół katolicki i Państwo są, każde w swojej dziedzinie, suwerenne, niezależne i autonomiczne oraz deklarują swoje zaangażowanie we wzajemnych relacjach

${ }^{14}$ „,considérant l'histoire de l'Eglise catholique et son implantation au Burundi avec la fondation des premières missions (Muyaga, Mugera, Buhonga, Kanyinya et Rugari) entre les années 1898 et 1909”. Tamże.

15 „considérant les bonnes relations qui existent entre l'Etat du Burundi et le Saint-Siège depuis la création d'une Nonciature Apostolique à Bujumbura, le 16 décembre 1962". Tamże. 
do respektowaniu tej zasady i współdziałania dla dobra duchowego, moralnego, społecznego, kulturowego i materialnego osoby ludzkiej, podobnie jak na rzecz promocji dobra wspólnego z poszanowaniem godności i praw osoby ludzkiej”'16.

Odwołanie się do zasady niezależności i autonomii państwa i Kościoła, każdego w swojej dziedzinie, stanowi w umowach Stolicy Apostolskiej z państwami - od czasu Soboru Watykańskiego $\mathrm{II}^{17}$ - pewien standard. W umowie burundyjskiej, jak widać, formułę tę uzupełniono o termin „suwerenność”, który jednak znaczeniowo nie dodaje niczego „dodatkowego” w stosunku do treści formuły „niezależność i autonomia".

Na uwagę zasługuje wzmianka o tym, iż zaangażowanie stron w respektowanie wspomnianej zasady i we współdziałanie we wzajemnych relacjach ma służyć określonym celom (dobru duchowemu, itd. osoby ludzkiej) oraz dobru wspólnemu, przy poszanowaniu godności i praw tejże osoby ludzkiej.

W art. 2 stwierdza się: „Respektując prawo do wolności religijnej i porządek publiczny, Republika Burundi zapewnia Kościołowi katolickiemu wolność pełnienia własnej misji apostolskiej, w szczególności w odniesieniu do kultu, zarządzania swoimi wiernymi, nauczania we wszystkich formach, prowadzenia dzieł dobroczynnych, działalności stowarzyszeń i instytucji, o których mowa w art. 3 i 4 niniejszej umowy ramowej"18.

Uznanie przez Państwo Burundyjskie prawa Kościoła katolickiego do pełnienia jego własnej misji jest wyrazem poszanowania zasady niezależności i autonomii wspólnoty religijnej i wspólnoty politycznej, każdej w swojej dziedzinie. Zapewnienie respektowania tego prawa należnego Kościołowi ex natura rei jest zwykłą powinnością państwa, wynikającą z zasady wolności religijnej, na którą się zresztą powołano.

Wyszczególnienie dziedzin należących do misji Kościoła ma charakter jedynie egzemplatywny, nie zaś taksatywny (wyczerpujący).

16 „Le Saint-Siège et la République du Burundi réaffirment que l'Eglise catholique et l'Etat sont, chacun dans son ordre, souverains, indépendants et autonomes, et déclarent s'engager, dans leurs relations, à respecter un tel principe et à oeuvrer ensemble pour le bien-être spirituel, moral, social, culturel et matériel de la personne humaine, ainsi qu'en faveur de la promotion du bien commun dans le respect de la dignité et des droits de la personne humane" (art. 1).

${ }^{17}$ Zob. Sacrosanctum Concilium Oecumenicum Vaticanum II, Constitutio pastoralis de Ecclesia in mundo huius temporis Gaudium et spes (7.12.1965), AAS 58 (1966), s. 1025-1115; tekst polski: Sobór WaTYKaŃSKi II, Konstytucje, dekrety, deklaracje, tekst polski, nowe thumaczenie, Pallottinum, Poznań 2002, s. 526-606, nr 76.

18 „Dans le respect du droit à la liberté religieuse et de l'ordre public, la République du Burundi assure à l'Eglise catholique le libre exercice de sa mission apostolique en particulier pour cequi concerne le culte, legouvernement de ses fidèles, l'enseignement sous toutes ses formes, les oeuvres de bienfaisance et les activités des associations et des institutions dont il est traité aux Articles 3 et 4 du présent Accord-cadre" (art. 2). 
Korzystanie z wolności Kościoła w pełnieniu własnej, wrodzonej mu misji zostało ograniczone jednie wymogami porządku publicznego.

Wypada zwrócić uwagę, że - w przeciwieństwie do innych umów (m.in. konkordatu polskiego z 28 lipca 1993 r. ${ }^{19}$ ) - nie dodano, iż gwarancja, o której mowa, dotyczy „swobodnego i publicznego” pełnienia przez Kościół własnej misji.

Artykuł 3 zawiera uznanie przez Państwo Burundyjskie osobowości prawnej Kościoła i jego instytucji.

W § 1 „Republika Burundi uznaje osobowość prawną Kościoła katolickiego, którą posiada ze swej natury"20.

W § 2 „Republika Burundi uznaje również osobowość prawną wszystkich instytucji Kościoła katolickiego, które ją mają na podstawie prawa kanonicznego i które rządzą się ich własnymi regułami"21.

W § 3, stanowiącym uszczegółowienie § 2, stwierdza się: „Republika Burundi uznaje w szczególności osobowość prawną Konferencji Biskupów Katolickich Burundi oraz wszystkich okręgów i instytucji, których lista wskazująca jest załączona do niniejszej umowy ramowej (Aneks), jak również wszystkich tych, w stosunku do których Nuncjatura Apostolska zaświadczy, że ostatnio zostały erygowane"22.

Wolno zauważyć, że - odmiennie w stosunku do innych umów - w normie tej nie przewiduje się powszechnej procedury nabywania osobowości prawnej (z wyjątkiem podmiotów o większym znaczeniu instytucjonalnym, jak Konferencja Biskupów) na drodze zwykłego wpisania do rejestru publicznego, na podstawie oficjalnej dokumentacji danego podmiotu kościelnego ${ }^{23}$. Tego rodzaju procedura została zastąpiona przez praktykę dokonującą się na drodze negocjacji (nie zaś

${ }^{19}$ Konkordat między Stolicą Apostolską i Rzecząpospolitą Polską z 28 lipca 1993 roku, Dz. U. z 1998 r. Nr 51, poz. 318, art. 5.

20 „La République du Burundi reconnaît la personnalité juridique que l'Eglise catholique possède par nature" (art. $3 \S 1)$.

${ }^{21}$ „La République du Burundi reconnaît également la personnalité juridique de toutes les institutions de l'Eglise catholique qui en bénéficient selon le droit canonique et qui restent régies par leurs règles propres" (art. $3 \S 2$ ).

22 „La République du Burundi reconnaît en particulier la personnalité juridique de la Conférence des Evêques Catholiques du Burundi et de toutes les circonscriptions et institutions, dont une liste indicative est jointe au présent Accord-cadre (Annexe), ainsi que toutes celles pour lesquelles la Nonciature Apostolique aura certifié qu'elles ont été érigées ultérieurement" (art. 3 § 3).

${ }^{23}$ Por. Konkordat między Stolicą Apostolską i Rzecząpospolitą Polską, art. 4 ust. 2; Accordo tra la Santa Sede la Repubblica di Capo Verde sullo statuto giuridico della Chiesa cattolica in Capo Verde - Acordo entre a Santa Sé e a República de Capo Verde relativo ao estatuto jurídico de Igreja católica em Capo Verde (10.06.2013), AAS 106 (2014), s. 220-241, art. 5 ust. 3; Zob. W. GóRALSKI, Gwarancje wolności religijnej w konkordacie między Stolica Apostolska i Republika Zielonego Przylądka, „Opolskie Studia Administracyjno-Prawne” 13 (2015), nr 4, s. 83. 
administracyjnej): odesłanie do obszernej listy okręgów i instytucji katolickich zamieszczonych w Aneksie do umowy.

Bezpośrednią konsekwencją gwarancji pomieszczonej w art. 3 jest uznanie swobody Kościoła w kanonicznym zarządzaniu własnymi instytucjami kościelnymi z jedynym obowiązkiem poinformowania władz świeckich w przypadku erygowania, zmiany lub zniesienia danej jednostki kościelnej.

Tak więc w art. $4 \S 1$ stanowi się, iż ,wyłącznie do władzy kościelnej należy swobodne stanowienie norm kanonicznych w zakresie własnych kompetencji, jak również erygowanie, dokonywanie zmian i znoszenie instytucji kościelnych w ogólności, jak i okręgów kościelnych i wszystkich kościelnych osób prawnych”24.

Wydaje się, że pierwsza część paragrafu dotycząca gwarancji swobodnego stanowienia przez władzę kościelną przepisów prawa kanonicznego w ramach swoich kompetencji powinna znaleźć swoje miejsce w odrębnej jednostce redakcyjnej, np. w art. $2^{25}$. Chodzi bowiem o materię znacznej rangi, która nieco sztucznie wybrzmiewa $\mathrm{w}$ artykule poświęconym powoływaniu do życia, modyfikowaniu i znoszeniu jednostek kościelnych.

W § 2 stanowi się, iż „w przypadku zniesienia instytucji kościelnej, do kompetencji władzy kościelnej należy przypisanie dóbr majątkowych danej osoby prawnej" 26 .

Natomiast $\S 3$ brzmi następująco: „Gdy Stolica Apostolska eryguje, modyfikuje lub znosi jakiś okręg kościelny, natychmiast informuje o tym władze burundyjskie"27.

Artykuł 5 zawiera gwarancje udzielone Kościołowi katolickiemu i jego wyznawcom swobodnego komunikowania się.

W § 1 „Republika Burundi gwarantuje Kościołowi katolickiemu, podobnie jak jego członkom, zarówno indywidualnym, jak i odpowiedzialnym albo członkom jego organizacji, wolność komunikowania się i utrzymywania relacji ze Stolicą Apostolską, z Konferencjami Biskupów innych krajów, podobnie jak z Kościołami partykularnymi, osobami i organizmami obecnymi wewnątrz kraju lub poza nim"28.

24 „Il appartient exclusivement à l'Autorité ecclésiastique de fixer librement les normes canoniques dans le domaine de sa compétence, ainsi que d'ériger, modifier ou supprimer les institutions ecclésiastiques en général, comme les circonscriptions ecclésiastiques et toutes les personnes juridiques ecclésiastiques" (art. $4 \S 1$ ).

${ }^{25}$ Por. Konkordat między Stolicą Apostolską i Rzecząpospolitą Polską, art. 5.

26 „Lorsqu'une institution ecclésiastique est supprimée, c'est l'Autorité ecclésiastique compétente qui décide de l'attribution des éléments du patrimoine de la personne juridique concernée" (art. 4 § 2).

27 „Lorsque le Saint-Siège érige, modifie ou supprime une circonscription ecclésiastique, il en informe aussitôt les Autorités burundaises" (art. 4 §).

${ }^{28}$ „La République du Burundi garantit à l'Eglise catholique ainsi qu'à ses membres, soit comme individus, soit en tant que responsables ou membres de ses organisations, la liberté de communiquer et de se maintenir en relation avec le Saint-Siège, avec les Conférences épiscopales d'autres pays, tout 
Z kolei w § 2 czytamy: „Dla uczynienia tego efektywnym i ułatwienia, Republika Burundi rozpatrzy z przychylnością prośby o wizy i zezwolenia na pobyt przedstawione przez duchownych lub osoby konsekrowane wysłane w misji do Burundi przez kompetentną władzę Kościoła katolickiego i, w przypadku udzielenia, wystawi je nieodpłatnie"29.

\subsection{SPRAWOWANIE KULTU BOŻEGO (ART. 6)}

Konsekwencją gwarancji wpisanej do art. 2 umowy ramowej w odniesieniu do swobodnego pełnienia przez Kościół własnej misji jest zapewnienie Państwa dotyczące sprawowania kultu Bożego, co też statuuje art. 6.

W $§ 1$ „Republika Burundi gwarantuje Kościołowi katolickiemu tożsamość znaków religijnych i tytułów"30.

„W ramach swojego ustawodawstwa, głosi § 2, Republika Burundi zapewnia nienaruszalność miejsc kultu (kościoły, kaplice, oratoria, cmentarze i ich przyległości), podobnie jak i symboli kultu"31.

W § 3, który stanowi uszczegółowienie $\S 2$, stwierdza się, że „wymienione miejsca kultu nie mogą być przeznaczone na inne cele, na sposób stały lub przejściowy, chyba że dla poważnych racji i za zgodą władzy diecezjalnej, od której zależą"32.

comme avec les Eglises particulières, personnes et organismes présents à l'intérieur ou à l'extérieur du pays" (art. $5 \S 1$ ); Por. Accordo tra la Santa Sede e la Repubblica de Guinea Equatoriale sulle relazioni tra la Chiesa Cattocica e lo Stato - Acordo entre la Repubblica de Guinea Ecuatorial y la Santa Sede sobre las relaciones entre la Iglesia Católica y El Estado (13.10.2012), AAS 105 (2013), s. 987-1000, art. 5; W. GóRALSKI, Wzajemne relacje Kościoła katolickiego i państwa w konwencji między Stolica Apostolska i Republika Gwinei Równikowej, „Przegląd Prawa Wyznaniowego” 7 (2015), s. 33. W 1976 r. Episkopaty Uganda-Urundi i Zair (dawne kolonie belgijskie) utworzyły Episkopat Krajów Wielkich Jezior (CEPEL) jako organizm międzynarodowy subregionalny. Z czasem zjawisko łączenia się Episkopatów regionalnych afrykańskich znacząco się rozszerzyło, o czym świadczy powstanie L'Association of Member Episcopal Conferences in Eastern Africa (AMECEA). Zob. H. Iwaka Kitambala, Les doits de l'homme en RD Congo et la geopolitique de l'integration dand les Pays de Grand Lacs. Une étude juridique de la contribution de l'ONU et de l'Eglise, Roma: Pontificia Università Lateranense 2012, s. 172 i 226.

29 „Pour rendre effectif et faciliter cela, la République du Burundi examinera avec bienveillance les demandes de visas et de permis de séjour présentées par des ecclésiastiques ou des personnes consacrées envoyés en mission au Burundi par l'Autorité compétente de l'Eglise catholique et, en cas de concession, les délivrera gratuitement" (art. 5 §).

30 „La République du Burundi garantit à l'Eglise catholique l'identité de ses signes religieux et ses titres" (art. $6 \S 1)$.

31 „Dans le cadre de sa législation, la République du Burundi assure l'inviolabilité des lieux de culte (églises, chapelles, oratoires, cimetières et leurs annexes), ainsi que des symboles du culte" (art. $6 \S 2$ ).

32 „Ces lieux de culte ne peuvent être destinés à d'autres usages, de façon permanente ou temporaire, que pour de graves motifs et avec l'accord explicite de l'Autorité diocésaine dont ils dépendent( (art. 6 § 3); Por. Konkordat między Stolicą Apostolską i Rzecząpospolitą Polską, art. 8 ust. 3. 
Artykuł 6 ust. 4 zawiera postanowienie, w myśl którego „w przypadku, w którym wymienione miejsca kultu stanowiłyby poważne i realne ryzyko dla bezpieczeństwa osób i dóbr, władze cywilne mogą i powinny podjąć wszystkie środki ochrony, z obowiązkiem uprzedzenia wcześnie, jak to tylko możliwe, władz kościelnych, to jest biskupa diecezji i osób bezpośrednio odpowiedzialnych za używanie kultowe budynków, o które chodzi" ${ }^{33}$.

\subsection{NOMINACJE KOŚCIELNE (ART. 7)}

Regulacje w dziedzinie nominacji kościelnych stanowią przedmiot art. 7 umowy ramowej.

W § 1 przyjęto zasadę generalną, iż „wszystkie nominacje kościelne, podobnie jak przydział obowiązków kościelnych są wyłącznie zastrzeżone Kościołowi katolickiemu, zgodnie z normami kanonicznymi" ${ }^{34}$.

W § 2 zaznacza się, iż „nominacja, przeniesienie, pozbawienie i przyjęcie rezygnacji biskupów należy do wyłącznej kompetencji Stolicy Apostolskiej”35.

Z kolei § 3 zawiera przepis, w myśl którego ,przed ogłoszeniem nominacji biskupa diecezjalnego Stolica Apostolska poda do wiadomości, poufnie i z tytułu kurtuazji, nazwisko elekta rządowi burundyjskiemu, który zachowa sekret aż do oficjalnej publikacji" ${ }^{\prime 36}$.

W § 4 strony przyjmują, że „każda nominacja, którą Państwo chce zastrzec dla jakiegoś kapłana lub członka Instytutu zakonnego mającego osobowość prawną w Kościele katolickim, powinna być przedmiotem pisemnego wniosku skierowanego do biskupa diecezjalnego, któremu podlega ten podmiot, albo przełożonego generalnego osoby, o którą chodzi. Swoje zgłoszenie dokonane przez Państwo powinna dobrze określić, gdy chodzi o czas, zobowiązania i o korzyści, które stąd

33 „Au cas où ces lieux de culte présenteraient des risques graves et avérés pour la sécurité des personnes ou des biens, les Autorités civiles peuvent et doivent prendre toutes mesures de protection, à charge pour elles d'avertir le plus tôt possibleles Autorités ecclésiastiques, c'est-à-dire l'Evêque du diocèse et la personne directement responsable de l'usage cultuel de l'édifice en question" (art. $6 \S 4$ ).

34 „Toutes les nominations ecclésiastiques ainsi que l'attribution des charges ecclésiastiques sont exclusivement réservées à l'Eglise catholique, en conformité avec les normes canoniques" (art. $7 \S 1$ ).

35 „La nomination, le transfert, la destitution et l'acceptation de la renonciation des Evêques relèvent de la compétence exclusive du Saint-Siège" (art. 7 §).

36 „Avant la publication de la nomination d'un Evêque diocésain, le Saint-Siège fera connaître confidentiellement et à titre de courtoisie le nom de élu au gouvernement burundais qui s'engage à le garder secret jusqu'à la publication officielle" (art. 7 §); por. Konkordat między Stolicą Apostolską i Rzecząpospolitą Polską, art. 7 ust. 4; Accordo tra la Santa Sede e la Repubblica de Guinea Equatoriale, art. 8 ust. 3; Accordo tra la Santa Sede la Repubblica di Capo Verde, art. 7 ust. 3. 
płyną, specjalna umowa między Państwem i biskupem lub wyższym przełożonym, która to umowa powinna respektować normy kanoniczne"37.

Tego rodzaju postanowienie ma niewątpliwie charakter oryginalny. Stwarza bowiem możliwość władzom państwowym występowania z inicjatywą do biskupa lub generalnego przełożonego zakonnego o zaangażowanie kapłana lub osoby zakonnej w jakiejś specjalnej posłudze. Wskazuje to na ducha współpracy między Kościołem i państwem oraz docenienia wkładu misyjnego i pastoralnego Kościoła w sferze społecznej ${ }^{38}$.

\subsection{PRZESTĘPSTWA DUCHOWNYCH I OSÓB ZAKONNYCH ORAZ SEKRETY: SPOWIEDZI I ZAWODOWY (ART. 8)}

W § 1 znalazł się następujący zapis: „W stosunku do jakiegokolwiek doniesienia lub dochodzenia dotyczących duchownego lub zakonnika (zakonnicy) co do podstawy ewentualnych zachowań niezgodnych z prawem Państwa, władze sądowe niezwłocznie poinformują poufnie biskupa miejsca zamieszkania zainteresowanego o motywach takich dochodzeń. Jeśli chodzi o zakonnika (zakonnicę), te same władze powiadomią również niezwłocznie jego bezpośredniego przełożonego"39.

$\mathrm{Z}$ kolei $\S 2$ zawiera postanowienie, w myśl którego „w przypadku biskupa lub kapłana wykonującego jurysdykcję równorzędną, zostanie powiadomiona Stolica Apostolska, za pośrednictwem Nuncjatury Apostolskiej"40.

Natomiast w § 3 czytamy: „Sekret spowiedzi jest absolutny i nienaruszalny. Nigdy więc nie dopuszcza się przesłuchiwania duchownego w tej materii. Biskupi, kapłani i zakonnicy (zakonnice) mają prawo do respektowania ich sekretu zawodowego"41.

37 „Toute nomination que l'Etat veut réserver à un prêtre ou à un membre d'un Institut religieux jouissant de la personnalité juridique dans l'Eglise catholique doit avoir été l'objet d'une demande écrite à l'Evêque diocésain dont dépend ce sujet ou au Supérieur Général de la personne concernée. Son engagement par l'Etat doit être bien défini, quant au temps, aux engagements et aux avantages qui en découlent, par une convention spécifique entre l'Etat et l'Evêque ou le Supérieur Général et qui soit respectueuse des normes canoniques" (art. $7 \S 4$ ).

${ }^{38}$ VECCHI, Il concordato del 2012, s. 581.

39 „Pour toute dénonciation ou poursuite concernant un clerc ou un religieux (religieuse) sur le fondement d'éventuels comportements incompatibles avec les lois de l'Etat, les Autorités judiciaires feront connaître sans délai et confidentiellement à l'Evêque du lieu du domicile de l'intéressé les motifsde telles poursuites. S'il sagit d'un religieux (religieuse) les mêmes Autorités avertiront sans délai aussi son supérieur direct" (art. $8 \S 1$ ).

40 „Dans le cas d'un Evêque ou d'un prêtre exerçant une juridiction assimilée, le Saint-Siège sera aussitôt informé, via la Nonciature Apostolique" (art. 8 § 2).

${ }^{41}$ „Le secret de la confession est absolu et par là inviolable. Il n'est donc jamais permis d'interroger un clerc en cette matière. Les Evêques, les prêtres et les religieux (religieuses) ont 


\subsection{DOBRA MATERIALNE KOŚCIELNYCH OSÓB PRAWNYCH ORAZ DUCHOWNYCH (ART. 9, 11 I 18)}

Dość szczegółowo potraktowano w umowie sprawy materialne kościelnych osób prawnych oraz duchowieństwa.

Artykuł 9 poświęcono sprawom materialnym kościelnych osób prawnych (nie instytucji kościelnych).

„Kościelne osoby prawne, stwierdza się w § 1, mogą nabywać, posiadać, dysponować i alienować dobra ruchome i nieruchome, podobnie jak prawa patrymonialne, w granicach ustawodawstwa kanonicznego i burundyjskiego"42.

W § 2 znalazł się zapis: „Kościelne osoby prawne mogą swobodnie otrzymywać ze strony wiernych darowizny i decydować o kwestach i wszelkich datkach przeznaczonych na pełnienie ich misji, z zachowaniem norm kanonicznych»43.

„Te same kościelne osoby prawne, statuuje $\S 3$, mogą zakładać fundacje, których działalność, gdy chodzi i jej skutki cywilne, będą podlegać normom ustawodawstwa burundyjskiego" 44 .

Wreszcie w $§ 4$ strony postanowiły, że „Państwo burundyjskie wyklucza wszelkie wywłaszczenie dóbr ruchomych i nieruchomych Kościoła katolickiego, ponieważ są one przeznaczone dla dobra wspólnoty. Nie dotyczy to dóbr prywatnych poszczególnych duchownych" ${ }^{\prime 2}$.

Tak więc uznano najpierw w umowie ramowej swobodne (różnorodne) działania kościelnych osób prawnych w stosunku do wszelkich dóbr, z zachowaniem zarówno norm prawa kanonicznego, jak i państwowego. Inaczej postąpiono w odniesieniu

droit au respect de leur secret professionnel" (art. 8 ust. 3); Analogiczną gwarancję zawiera umowa Stolicy Apostolskiej z Republiką Zielonego Przylądka, która dotyczy sekretu posługi kapłańskiej, w szczególności tajemnicy spowiedzi sakramentalnej, podobnie jak zapewnienie, w myśl którego duchowni nie mogą być przesłuchiwani przez sędziów w trybunałach państwowych lub przez inne władze w sprawie faktów i spraw, które poznali z racji pełnienia swojej posługi. Zob. Accordo tra la Santa Sede la Repubblica di Capo Verde, art. 9 ustt. 1-2.

42 „Les personnes juridiques ecclésiastiques peuvent acquérir, posséder, disposer etaliéner des biens mobiliers et immobiliers, comme des droits patrimoniaux, dans le cadre des législations canonique et burundaise" (art. $9 \S 1$ ).

43 „Les personnes juridiques ecclésiastiques peuvent librement recevoir de la part des fidèles des dons et décider de quêtes et de toute contribution destinée à l'accomplissement de leur mission dans le respect des normes canoniques" (art. $9 \S 2$ ).

${ }^{44}$ „Ces mêmes personnes juridiques ecclésiastiques peuvent instituer des fondations, dont les activités, quant à leurs effets civils, seront soumises aux normes légales burundaises" (art. $9 \S 3$ ).

45 „L'Etat burundais exclut toute expropriation des biens meubles et immeubles de l'Eglise catholique, parce qu' ils sont destinés au bien de la communauté. Cela ne concerne pas les biens privés desindividus ecclésiastiques" (art. 9 § 4). 
do darowizn i zbiórek przeznaczonych na cele związane z urzeczywistnianiem zadań tychże osób prawnych, gdzie wiążą jedynie przepisy kanoniczne.

W stosunku do działalności fundacji kościelnych osób prawnych, jeśli działalność ta miałaby skutkować na forum państwowym, konsekwentnie postawiono wymóg zachowania w tej materii przepisów państwowych.

Gdy chodzi o wywłaszczanie dóbr, takie działanie uznano za niemożliwe, jeśli dobra te służą danej wspólnocie kościelnej; natomiast nie odniesiono tej opcji w stosunku do dóbr prywatnych duchowieństwa.

Co się tyczy duchownych, to $\mathrm{w}$ art. $11 \S 1$ postanowiono, że oni, ich dobra oraz dobra kościelnych osób prawnych podlegają opodatkowaniu z tego samego tytułu, co osoby i dobra obywateli Republiki Burundi, stosownie do obowiązującego ustawodawstwa burundyjskiego"46.

W § 2 powołanego artykułu czytamy: „Wyjątek stanowią od tego, co przewiduje art. $11 \S 1$, a więc nie są w ogóle podległe opodatkowaniu: miejsca, przedmioty, księgi i budynki przeznaczone do służby bożej, importowanie, drukowanie i sprzedaż wydań Pisma Świętego publikowanego z autoryzacją władzy kościelnej, seminaria kościelne, domy formacyjne zakonników (zakonnic) i prace konieczne do ich budowania lub do ich przebudowy, dobra i tytuły, z których dochody są przeznaczone na potrzeby kultu religijnego oraz programy kulturalne i społeczne, i nie przysparzają dochodów osobistych beneficjariuszy ${ }^{47}$.

$\mathrm{W}$ art. 18 uregulowano sprawy wywłaszczeń. Tak więc w $\S 1$ stwierdza się: „Republika Burundi uznaje, że Państwo wywłaszczyło dobra należące do Kościoła katolickiego i których większość zwróciła różnym diecezjom i kongregacjom w ciągu lat 1987-1990"48.

Z kolei w $§ 2$ strony postanowiły, że „gdy chodzi o inne dobra i własności wywłaszczone na rzecz użyteczności publicznej, zostanie przestudiowana moż-

46 „Les ecclésiastiques, leurs biens et les biens des personnes juridiques ecclésiastiues sont imposables au même titre des personnes et des biens citoyens de la République du Burundi, conformément à la législation burundaise en vigeur" (art. $11 \S 1$ ).

47 „Font exception à ce que prévoit l'Art. $11 \S 1$ et donc ne sont pas du tout imposables: les lieux, les objets, les livres et les édifices consacrés au service divin, l'importation, l'impression et la vente des éditions de la Sainte Bible publiées avec l'autorisation de l'Autorité ecclésiastique, les séminaires ecclésiastiques, les maisons de formation des religieux (religieuses) et les travaux nécessaires pour leur construction ou pour leur réaménagement, les biens et les titres dont les revenus sont destinés aux besoins du culte religieux et aux programmes culturels et sociaux et ne contribuent pas aux revenus personnels des bénéficiaires" (art. 11 § 2).

48 „La République du Burundi reconnaît que l'Etat a exproprié des biens appartenant à l'Eglise catholique et dont la majorité a été rétrocédée aux" (art. 18 §1). 
liwość ich oddania, stosownie do okoliczności i czasów, które zostaną ustalone przez komisję mieszaną ad hoc"49.

W latach 1987-1990 Państwo Burundi (III Republika) prowadziło politykę restytucji dóbr skonfiskowanych diecezjom i kongregacjom zakonnym. Nic też dziwnego, że, jak już wyżej powiedziano, w art. 9 § umowy ramowej Państwo burundyjskie wykluczyło wszelkie wywłaszczenie dóbr ruchomych i nieruchomych Kościoła katolickiego jako służących dobru wspólnoty.

\subsection{BUDOWNICTWO SAKRALNE I KOŚCIELNE (ART. 10)}

W dziedzinie budownictwa sakralnego i kościelnego strona kościelna otrzymała stosowne gwarancje, które stanowią wyraz uznania Państwa burundyjskiego dla niejako naturalnych potrzeb Kościoła.

W art. $10 \S 1$ czytamy, że „W granicach ustawodawstwa cywilnego, Kościół katolicki ma prawo do budowy kościołów i budynków kościelnych, rozbudowy i modyfikowania ich konfiguracji. W tym ostatnim aspekcie rozumie się również wszystkie kościoły i wszystkie budynki już istniejące" ${ }^{50}$.

Wydaje się, że owa klauzula końcowa nie jest potrzebna, trudno bowiem modyfikować coś, co nie istnieje.

$\mathrm{W} \S 2$ artykułu stanowi się, iż ,jedynie biskup diecezjalny lub osoba kanonicznie zrównana z nim może decydować o stosowności budowania nowych kościołów albo nowych budynków kościelnych na terenie ewentualnie uzgodnionym w tym celu z Państwem lub który zostanie nabyty zgodnie z obowiązującymi przepisami: w tym ostatnim przypadku, biskup lub osoba kanonicznie z nim zrównana poinformuje kompetentne władze cywilne" ${ }^{\text {I1 }}$.

Brzmienie $\S 3$ jest następujące: „W konsekwencji, te same władze nie wezmą pod uwagę wniosków dotyczących budowania kościołów, jak tylko po otrzymaniu

49 „Pour d'autres biens ou propriétés expropriés pour cause d'utilitépublique, la possibilité de rétrocession sera étudiée selon les modalités et temps qui seront établis par une commission mixte ad hoc" (art. $18 \S 2)$.

50 „Dans le cadre de la législation civile, l'Eglise catholique a le droit de construire des églises et des édifices ecclésiastiques, d'en agrandir et d'en modifier la configuration. Ce dernier aspect s'entend aussi de toutes les églises et de tous les édifices déjà existants" (art. $10 § 1$ ).

51 „Seul l'Evêque diocésain ou la personne à lui canoniquement assimilée peut décider de l'opportunité de construire de nouvelles églises ou de nouveaux édifices ecclésiastiques sur un terrain éventuellement accordé àcet Effel par l'Etat ou qui aura été acquis dans le cadre des règlements en vigueur: en ce dernier cas, l'Evêque ou la personne à lui canoniquement assimilée informera les Autorités civiles compétentes" (art. $10 \S 2$ ). 
pisemnej zgody biskupa diecezjalnego lub osoby kanonicznie z nim zrównanej na terenie, na którym jest zaprojektowana budowla"52.

Przytoczone regulacje stanowią standard przyjmowany w tym zakresie w analogicznych umowach dwustronnych ${ }^{53}$.

\subsection{POSŁUGIANIE SIĘ PRZEZ KOŚCIÓŁ ŚRODKAMI PRZEKAZU (ART. 12)}

Art. 12 umowy ramowej, poświęcony posługiwaniu się przez Kościół środkami przekazu, w $\S 1$ zawiera gwarancję daną temuż Kościołowi „swobodnego dostępu do środków publicznych komunikowania (prasa, radio, telewizja, środki telepatyczne). Kościół katolicki, dodano, posiada prawo do tworzenia i bezpośredniego zarządzania radiem i telewizją, zgodnie z obowiązującym prawem"s4.

Z kolei w $§ 2$ przyjęto, że „również uznaje się stosunku do Kościoła katolickiego swobodę wydawania, publikowania, rozpowszechniania i sprzedawania książek, gazet, czasopism i materiałów audiowizualnych oraz generalnie organizowania wszelkiej działalności ściśle związanej z misją duchową, z zachowaniem porządku publicznego, godności i wolności obywateli" ${ }^{55}$.

Wydaje się, że gwarancje udzielone w drugiej części paragrafu (swoboda organizowania wszelkiej działalności ściśle związanej z misja duchową Kościoła) dotyczy działalności nie tylko w sferze posługiwania się środkami komunikowania, lecz „wszelkiej działalności” Kościoła, a więc w różnych dziedzinach, a o tym mówi się w art. 2.

Poza tym, klauzula końcowa: „z zachowaniem porządku publicznego, godności i wolności obywateli" wydaje się niezbyt odpowiednia i nosi na sobie odżywające ślady obciążenia ideologicznego pochodzącego z dawnego reżimu nietolerancji religijnej ${ }^{56}$.

52 „En conséquence, ces mêmes Autorités ne prendront en considération les demandes concernant la construction d'églises qu'après avoir reçu l'accord écrit de l'Evêque diocésain ou de la personne à lui canoniquement assimilée, sur le territoire desquels est projetée la construction"(art. $10 \S 3$ ).

${ }^{53}$ Zob. Konkordat między Stolicą Apostolską i Rzecząpospolitą Polską, art. 24; Accordo tra la Santa Sede la Repubblica di Capo Verde, art. 6.

54 „Il est garanti à l'Eglise catholique un libre accès aux moyens publics de communication (journaux, radio, télévision et moyens télématiques). L'Eglise catholique possède le droit de créer et de gérer directement radios et télévisions, conformément à la législation en vigueur" (art. $12 \S 1$ ).

55 „De même, il est reconnu à l'Eglise catholique la liberté d'éditer, de publier, de divulguer et de vendre des livres, journaux, revues et matériel audiovisuel, et en général la liberté d'organiser toute activité étroitement liée à sa mission spirituelle, sous réserve du respect de l'ordre public, dela dignité et de la liberté des citoyens" (art. $12 \S 2$ ).

${ }^{56}$ Zob. J. Ndikumasabo, Paix et justice et éducation à ses valeurs du Burundi à la lumière des messages ponificaux pour la Journée mondiale de la paix, Roma: Università Pontificia Salesiana 2004, s. 302 i 318; VeCCHI, Il concordato del 2012, s. 583. 


\subsection{MAŁŻEŃSTWO (ART. 13)}

W bardzo lapidarnie sformułowanym art. 13 znalazł się zapis: „Z racji wartości duchowej, moralnej i wychowawczej małżeństwa kanonicznego, Republika Burundi uznaje jego szczególne znaczenie w budowaniu rodziny w łonie narodu ${ }^{57 "}$.

Tego rodzaju sformułowanie zdaje się wskazywać bardziej na jego charakter apologetyczny (pochwała małżeństwa kanonicznego) niż jurydyczny (brak norm prawnych); w sposób ,jałowy" i zupełnie niewystarczający w aspekcie prawnym traktuje małżeństwo kanoniczne. Odbiega zdecydowanie od standardów przyjętych w umowach konkordatowych państw (m.in. afrykańskich) ze Stolica Apostolską ${ }^{58}$.

W powołanym artykule zabrakło przede wszystkim kwestii dotyczących uznawania na forum państwowych skutków małżeństwa kanonicznego (pod określonymi warunkami), uznawania (lub nie) orzeczeń kanonicznych w sprawach nullitatis matrimonii czy dyspens papieskich super rato. Poza tym nie wspomniano w ogóle o rodzinie. Ów deficyt regulacji w tak znaczących sprawach budzi tym większe zdziwienie, że konstytucja burundyjska z 18 marca 2005 r., pod rządami której została zawarta umowa ramowa, zawiera szereg stwierdzeń pozytywnie świadczących o docenianiu przez państwo instytucji małżeństwa i rodziny ${ }^{59}$.

57 „En raison de la valeur spirituelle, morale et éducative du mariage canonique, la République du Burundi lui reconnaît une importance particulière dans l'édification de la famille au sein de la Nation" (art. 13).

${ }^{58}$ Tak np. w umowie Stolicy Apostolskiej z Gwineą Równikową państwo uznaje wszystkie skutki cywilne małżeństwa zawartego zgodnie z przepisami prawa kanonicznego; dla skuteczności jednak takiego uznania kompetentna władza kościelna powinna podesłać autentyczną kopię aktu małżeństwa kompetentnemu urzędnikowi państwa, które ma obowiązek dokonania wpisu małżeństwa do rejestru cywilnego. Zob. Accordo tra la Santa Sede e la Repubblica de Guinea Equatoriale, art. 12. W analogicznej umowie z Republiką Zielonego Przylądka zawarta jest gwarancja dotycząca uznania przez Państwo skutków cywilnych małżeństwa zawartego zgodnie z prawem kanonicznym. Warunkiem uzyskania takich skutków jest sporządzenie aktu małżeństwa w odpowiednich rejestrach urzędu stanu cywilnego. Jednocześnie stanowi się, iż zapowiedzi przedślubne powinny mieć miejsce w odnośnych kościołach parafialnych oraz we właściwych urzędach stanu cywilnego. Skutki cywilne może uzyskać (po spełnieniu określonych warunków) także małżeństwo zawarte in articulo mortis, w bliskości porodu albo natychmiastowego zawarcia małżeństwa za wyraźną zgodą własnego ordynariusza miejsca. Zob. Accordo tra la Santa Sede la Repubblica di Capo Verde, art. 11 ust. 1 i 3.

${ }^{59}$ W konstytucji Republiki Burundi z 18 marca 2005 r. znalazły się następujące stwierdzenia: „Każda kobieta i każdy mężczyzna ma prawo do poszanowania swojego życia prywatnego i do swojego życia rodzinnego, do swojego mieszkania i swoich osobistych kontaktów”, art. 28 („Toute femme, tout homme a droit au respect de sa vie privée et de sa vie familiale, de son domicile et de ses communications personnelles”); „Gwarantuje się wolność w zawieraniu małżeństwa, podobnie prawo wyboru swojego lub swojej partnerki. Małżeństwo nie może być zawarte, jak tylko z wolną i pełną zgodą przyszłych małżonków. Małżeństwo między dwiema osobami tej samej płci jest zakazane”, art. 29 („La liberté de se marier est garantie, de même que le droit de choisir son ou sa partenaire. Le mariage ne peut être conclu qu'avec le libre et plein consentement des futurs époux. 
Nieuwzględnienie w umowie tak ważnych kwestii można przypisać, jak się wydaje, splotowi wielu zjawisk natury obyczajowo-kulturowej w odniesieniu do instytucji małżeństwa i rodziny. Tak więc należałoby tutaj wskazać: relatywizowanie małżeństwa jako związku nierozerwalnego, powstanie nowych modeli związków (szczególnie w dużych centrach), atawistyczne zwyczaje panujące w rodzinach, wzrost liczby par rozwiedzionych, żyjących w separacji lub w nowych związkach, istniejące jeszcze (nikłe) ślady bigamii czy zwyczajny rozziew między Ewangelią i rodziną, czy zakorzenione tradycje obyczajowe w tylu regionach kraju nadal żywotne, nakazujące postrzegać węzeł małżeński bardziej jako umowę między klanami niż jako prywatny pakt oblubieńczy między dwiema osobami traktowanymi indywidualnie, jako sprawcy przymierza małżeńskiego ${ }^{60}$.

Niewątpliwie te i inne zjawiska powinny angażować Kościół lokalny do aktywności pastoralnej o charakterze inkulturacji.

\subsection{ZRZESZANIE SIĘ WIERNYCH (ART. 14)}

W art. 14 układające się strony przyjęły następujące uzgodnienie: „Republika Burundi uznaje i chroni prawo wiernych katolików zrzeszania się według norm prawa kanonicznego w celu specjalnych aktywności misji Kościoła. Podlegając ustawodawstwu burundyjskiemu w tym, co dotyczy aspektów cywilnych ich aktywności, stowarzyszenia te, z uwagi na charakter interesu ogólnego, będą mogły jednak korzystać, w stosunku do pewnych aspektów ich statutów i ich zdolności prawnej, ze szczególnych dyspozycji, które zostaną bliżej określone w porozumieniu między Konferencją Biskupów Katolickich Burundi i rządem Republiki Burundi, przedstawionym Stolicy Apostolskiej" 61 .

Le mariage entre deux personnes de même sexe est interdit”); „Rodzina jest komórką o podstawie naturalnej społeczeństwa. Małżeństwo jest tego prawowitą podstawą. Rodzina i małżeństwo pozostają pod szczególną opieką państwa. Rodzice mają naturalne prawo i obowiązek kształcenia i wychowania swoich dzieci. W zadaniu tym są wspierani przez państwo i instytucje publiczne. Każde dziecko ma prawo ze strony swojej rodziny, społeczeństwa i państwa do środków specjalnego wsparcia, którego wymaga jego status małoletniego”, art. 30 („La famille est la cellule de base naturelle de la société. Le mariage en est le support légitime. La famille et le mariage sont placés sous la protection particulière de l'État. Les parents ont le droit naturel et le devoir d'éduquer et d'élever leurs enfants. Ils sont soutenus dans cette tâche par l'État et les collectivités publiques. Tout enfant a droit, de la part de sa famille, de la société et de l'État, aux mesures de protection spéciale qu'exige sa condition de mineur"), Constitution du Burundi, art. 28-30.

${ }^{60}$ I.M. Kazina, Proposition pour une pastorale familiale au Burundi, „Au Coer de l'Afrique” 1-2 (2002), s. 139-175; Zob. także Testi consultabili, [w:] Codes et lois, red. R. Bellon, P. Delfosse, Bruxelles-Bujumbura: Maison Fedinand Larcier 1970, s. 113-114 i 116.

61 „La République du Burundi reconnaît et protège le droit des fidèles Catholiques de s'associer selon les normes du droit canonique pour des activités spécifiques de la mission de l'Eglise. Tout 
Postanowienie to stanowi wyraz zrozumienia państwa dla znaczącego sektora aktywności duszpasterskiej Kościoła, jakim są stowarzyszenia wiernych, których działalność statutowa niejednokrotnie służy nie tylko dobru wiernych, lecz także dobru ogólnemu. Wydaje się, że wymóg przedstawienia wspomnianego porozumienia Stolicy Apostolskiej jest zbędny.

\subsection{PROWADZENIE PRZEZ KOŚCIÓŁ PLACÓWEK OŚWIATOWYCH I WYCHOWAWCZYCH (ART. 15)}

Mając na uwadze zaangażowanie Kościoła w dzieło edukacyjne i wychowawcze, $\mathrm{w}$ art. 15 umowy ramowej uregulowano ten właśnie rodzaj jego posługi.

W § 1 stwierdza się: „Uznaje się prawo Kościoła katolickiego zakładania, zarządzania i kierowania centrami nauczania i wychowania na wszystkich poziomach, a więc przedszkoli, szkół podstawowych i średnich, uniwersytetów i wydziałów, seminariów i wszystkich innych instytutów formacyjnych, w granicach prawa cywilnego i w zgodności z normami prawa kanonicznego i doktryny katolickiej"62.

Natomiast w $§ 2$ ustalono, iż ,ze względu na doświadczenie Kościoła katolickiego w dziedzinie wychowania szkolnego i na jakość jego wychowania oraz na znaczącą sieć jego infrastruktury w tym zakresie, Republika Burundi angażuje się w harmonijne współdziałanie z Konferencją Biskupów Katolickich Burundi w celu sporządzenia porozumienia gwarantującego lepszy wkład Kościoła w tej dziedzinie, przedstawionego Stolicy Apostolskiej"63.

Tak sformułowany przepis świadczy o dużym uznaniu Państwa burundyjskiego w stosunku do aktywności Kocioła w sferze wychowawczej. I tu jednak klauzulę o konieczności przedłożenia Stolicy Apostolskiej porozumienia Konferencji Biskupów i Państwa wolno uznać za niepotrzebną.

en étant soumises à la législation burundaise en ce qui concerne les aspects civils de leurs activités, cesassociations, en raison du caractère d'intérêt général, pourront bénéficier toutefois, pour certains aspects de leurs statuts et de leur capacité juridique, de dispositions particulières à préciser dans une entente entre la Conférence des Evêques Catholiques du Burundi et le gouvernement de la République du Burundi à soumettre au Saint-Siège" (art. 14).

${ }^{62}$ „Il est reconnu à l'Eglise catholique le droit d'instituer, de gérer et de diriger des centres d'instruction et d'éducation à tous les niveaux, tels que: écoles maternelles, primaires et secondaires, universités et facultés, séminaires et tout autre institut de formation, dans le cadre des lois civiles et aux normes du droit canonique et à la doctrine catholique" (art. $15 \S 1$ ).

63 „Eu égard à l'expérience de l'Eglise catholique en matière d'éducation scolaire, à la qualité de son éducation et au réseau important de ses infrastructures en ce domaine, la République du Burundi s'engage à oeuvrer de concert avec la Conférence des Evêques Catholiques du Burundi pour rédiger une entente garantissant la meilleure contribution de l'Eglise en ce domaine, à soumettre au Saint-Siège" (ar. $15 \S 2)$. 
W art. 16 układające się strony stwierdzają, iż „zgodnie z art. 3, Kościół katolicki może swobodnie zakładać instytucje służące realizowaniu aktywności dobroczynnej i pomocy społecznej związanej z jego misją duchową i charytatywną poprzez własne instytucje zdrowotne i pomocy społecznej. W tym celu Kościół będzie działał według własnych zasad określonych przez doktrynę Kościoła i w granicach ustawodawstwa cywilnego" ${ }^{\text {". }}$.

Odwołując się do art. 3 umowy (uznanie przez Państwo osobowości prawnej Kościoła katolickiego i jego instytucji), a także do misji Kościoła, strona państwowa udzieliła gwarancji swobodnego urzeczywistnianie tejże misji w zakresie, o którym mowa.

Wydaje się, że w drugim zdaniu artykułu, zamiast zwrotu ,według własnych zasad określonych przez doktrynę Kościoła” bardziej właściwe byłoby sformułowanie „według norm prawa kanonicznego” (ewentualnie: „według własnych zasad określonych przez doktrynę Kościoła i normy prawa kanonicznego").

\subsection{UDZIAŁ FINANSOWY PAŃSTWA W DZIAŁALNOŚCI KOŚCIOŁA NA RZECZ NARODU (ART. 17)}

Artykuł 17 został poświęcony udziałowi finansowemu Państwa w działalności Kościoła katolickiego na rzecz narodu burundyjskiego. Czytamy w nim: „Kompetentne władze Republiki Burundi i Konferencja Biskupów Katolickich Burundi zawrą wspólne porozumienie co o sposobu współpracy między nimi oraz udziału finansowego Państwa w stosunku do Kościoła katolickiego dla posługi, którą pełni dla narodu w dziedzinie zdrowia, pomocy społecznej i medycznej, wychowania i rozwoju, bez dyskryminacji z powodu respektowania doktryny Kościoła"65.

Artykuł ten zapowiada więc współdziałanie Państwa i Kościoła katolickiego w określonych dziedzinach, które należą do misji Kościoła, a jej urzeczywistnianie w tym zakresie służy dobru narodu, a więc obywateli. Przedmiotem porozumienia

64 „Conformément à l'article 3, l'Eglise catholique peut créer librement des institutions pour exercer des activités de bienfaisance et d'assistance sociale liées à sa mission spirituelle et caritative à travers ses propres institutions sanitaires et d'assistance sociale. Pour ce faire, elle agira selon les principes établis par la doctrine de l'Eglise et dans le cadre de la législation civile" (art. 16).

${ }^{65}$ „Les Autorités compétentes de la République du Burundi et la Conférence des Evêques Catholiques du Burundi fixeront d'un commun accord la façon de collaborer entre elles et la participation financière de l'Etat qui en dérive à l'Eglise catholique pour les services qu'elle rend à la nation dans les domaines de la santé, de l'assistance sociale et médicale, de l'éducation et du développement, sans qu'ils subissent des discriminations à cause du respect de la doctrine de l'Eglise" (art. 17). 
będzie również wsparcie finansowe Państwa w prowadzeniu przez Kościół dzieł w obszarach wymienionych w normie. Zrozumiała jest tutaj klauzula końcowa, w myśl której z owej posługi Kościoła będą mogli korzystać wszyscy obywatele, a nie tylko uznający jego doktrynę.

Czymś znamiennym jest $\mathrm{w}$ artykule to, że nie wymaga on, by zapowiedziane porozumienie Państwa i krajowego Episkopatu było przedstawione Stolicy Apostolskiej.

\subsection{OPIEKA DUSZPASTERSKA NAD ZAANGAŻOWANYMI \\ W SIŁACH ZBRONYCH I W SIŁACH BEZPIECZEŃSTWA \\ ORAZ NAD PREBYWAJACYMI W ZAKŁADACH \\ I INSTYTUTACH ZAMKNĘTYCH (ART. 19)}

W art. 19 układające się strony uzgodniły stanowisko w sprawie opieki duszpasterskiej nad pełniącymi służbę wojskową i w siłach bezpieczeństwa oraz nad przebywającymi w zakładach i instytutach tzw. zamkniętych.

W § 1 postanowiono, iż „Republika Burundi uznaje i gwarantuje Kościołowi katolickiemu prawo wykonywania swoich powinności duszpasterskich w stosunku do wiernych zaangażowanych w Siłach zbrojnych i w Siłach bezpieczeństwa, a także tych, którzy przebywają w zakładach penitencjarnych i szpitalnych oraz w instytutach opieki zdrowotnej, szkolnych i społecznych, o charakterze publicznym lub prywatnym"66.

Natomiast w $\S 2$ stwierdza się: „Działalność duszpasterska wykonywana w instytutach publicznych wymienionych $\mathrm{w} \S 1$ będzie przedmiotem porozumienia między Państwem Burundi i Konferencją Biskupów Katolickich Burundi podlegającego aprobacie Stolicy Apostolskiej" ${ }^{67}$.

Jak widać, w § 1 opieka duszpasterska nad kategoriami osób przebywających w zakładach i instytutach tam wymienionych została zagwarantowana niezależnie od tego, czy są to placówki publiczne czy prywatne. Natomiast w $§ 2$ to rozróżnienie poczyniono poprzez pomieszczenie klauzuli, w myśl której sprawa opieki duszpasterskiej nad przebywającymi w instytutach publicznych wymaga

66 „La République du Burundi reconnaît et garantit à l'Eglise catholique le droit d'exercer ses responsabilités pastorales envers les fidèles engagés dans les Forces armées et les Forces de sécurité, ainsi que ceux qui séjournent dans des établissements pénitentiaires et hospitaliers, comme dans des institutes d'assistance médicale, scolaire et sociale, de nature publique ou privée" (art. $19 \S 1$ ).

${ }^{67}$ „Les activités pastorales exercées dans les institutions publiques évoquées au $\$ 1$ feront l'objet d'une entente entre l'Etat du Burundi et la Conférence des Evêques Catholiques du Burundi, à soumettre à l'approbation duSaint-Siège" (art.19 § 2). 
uzgodnienia między Państwem i Konferencją Biskupów, przy czym uzgodnienie to winna zatwierdzić Stolica Apostolska.

Wydaje się, że wymóg zatwierdzenia owego uzgodnienia przez Stolicę Apostolska jest zbędny.

\subsection{POSTANOWIENIA KOŃCOWE (ART. 20-22)}

Wśród postanowień końcowych umowy ramowej znalazły się trzy artykuły, w których uzgodniono kwestie formalne.

Artykuł 20 poświęcono specjalnym porozumieniom, których zawarcie zostało zapowiedziane w odnośnych artykułach traktatu.

W § 1 stanowi się, że „specjalne porozumienia, o których w art. 14, 15, 17, 18 i 19, zostaną przygotowane przez komisje mieszane powołane ad hoc"68.

$\mathrm{W} \S 2$ przyjęto, że „w zakresie, w którym nie pozostają w sprzeczności z tym, co jest przewidziane w obecnej umowie ramowej, wcześniejsze porozumienia zawarte między Rządem Burundi i Konferencją Biskupów Katolickich Burundi pozostają w mocy tak długo, dopóki nie zostaną zmodyfikowane. W szczególności chodzi o: «Porozumienie szkolne» z 28 lutego 1990 r.; «Sposoby stosowania Konwencji szkolnej między Kościołem katolickim i Państwem Burundi» z 26 lipca 1990 r.; «Protokół z umowy dotyczącej Niższych Seminariów» z 10 czerwca 1993 r.; «Porozumienie o Kapelanii» z 1993 r.; «Porozumienie określające Ramy Ogólne Współpracy między Państwem Burundi i Kościołem Katolickim» z 18 sierpnia 2000 r.; «Umowa specjalna określająca ramy współpracy w dziedzinie zdrowia» z 31 marca 2009 r.; «Sposoby stosowania Umowy specjalnej o współpracy w dziedzinie zdrowia» z 31 marca 2009 r." 69

W art. 21 określono następująco tryb usuwania różnic dotyczących interpretacji i stosowania dyspozycji umowy ramowej: „Stolica Apostolska i Republika Burundi wyrażają zgodę na regulowanie na drodze dyplomatycznej wszystkich różnic

68 „Les accords spécifiques évoqués aux articles $14,15,17,18$ et 19 seront préparés par des commissions mixtes ad hoc" (art. $20 \S 1$ ).

69 „Dans la mesure où elles ne sont pas en contradiction avec ce qui est prévu dans le présent Accord-cadre, les précédentes conventions établies entre le Gouvernement du Burundi et la Conférence des Evêques Catholiques du Burundi restent en vigueur aussi longtemps qu'elles n'auront pas été modifiées. Il s'agit notamment de: la «C onvention scolaire » du 28 février 1990; les « M odalités d'application de la Convention scolaire entre l'Eglise catholique et l'Etat du Burundi » du 26 juillet 1990; le « Protocole d'Accord relatif aux Petits Séminaires » du 10 juin 1993; la «C onvention d'Aumônerie » de 1993; la « C onvention portant Cadre Général de Collaboration entre l'Etat du Burundi et l'Eglise Catholique » du 18 août 2000; 1' «A ccord spécifique portant cadre de collaboration dans le domaine de la santé » du 31 mars 2009; les « M odalités d'application de l'Accord spécifique de collaboration dans le domaine de la santé » du 31 mars 2009" (art. 20 § 2). 
opinii, które mogą powstać w interpretacji i w stosowaniu dyspozycji zawartych w obecnej umowie ramowej" 70 .

W przypadku zatem ewentualnych rozbieżności między stronami zarówno w wykładni, jak i w stosowaniu przepisów umowy, rozstrzygnięcia dokonują same strony (Stolica Apostolska poprzez Nuncjaturę Apostolską, a Republika Burundi poprzez Rząd).

Artykuł 22 zawiera klauzulę ratyfikacyjną umowy ramowej.

W § 1 postanowiono, że „obecna umowa ramowa zostanie ratyfikowana według procedury przewidzianej przez własne przepisy konstytucyjne układających się stron i wejdzie w życie po wymianie dokumentów ratyfikacyjnych"71.

Natomiast $\mathrm{w} \S 2$ uzgodniono, iż „w przypadku, w którym jedna $\mathrm{z}$ układających się stron uzna, że elementy związane z regulacją niniejszej umowy ramowej uległy takim zmianom, że czymś koniecznym stały się modyfikacje, obie strony zdecydują, wspólną zgodą, o otwarciu negocjacji”’72.

\section{ANEKSY}

W aneksach do umowy ramowej zamieszczono kilka wykazów. W nawiązaniu do art. $3 \S 3$ tegoż traktatu podano najpierw wykaz okręgów i instytucji Kościoła katolickiego: 1) Konferencja Biskupów Katolickich Burundi oraz związane z nią: cztery Wyższe Seminaria Duchowne, Centrum Pomocy i Rozwoju - Caritas Burundi Księgarnia św. Pawła, Prasa („Lavigerie”), Zaopatrzenie Diecezji Burundi; 2) dwie prowincje kościelne (Bujumbura i Gitega); 3) osiem diecezji katolickich i związane z nimi instytucje: w archidiecezji Bujumbura: Niższe Seminarium w Kanyosha, Organizacja Rozwoju Archidiecezji Bużumbura; w archidiecezji Gitega: Niższe Seminarium w Mugera, Organizacja Rozwoju w Archidiecezji Gitega; w diecezji Bubanza: Niższe Seminarium w Ciya, Biuro Diecezjalne Rozwoju w Bubanza; w diecezji Bururi: Niższe Seminarium w Buta; Rada ds. Wychowania Rozwoju; w diecezji Muyinga: Niższe Seminarium w Rusengo, Organizacja Diecezjalna Po-

70 „Le Saint-Siège et la République du Burundi s'accordent pour régler par la voie diplomatique toutes les divergences d'opinion qui pourraient surgir dans l'interprétation et dans l'application des dispositions contenues dans le présent Accord-cadre" (art. 21).

${ }^{71}$ „Le présent Accord-cadre sera ratifié selon les procédures prévues par les règles constitutionnelles propres aux Hautes Parties Contractantes et entrera en vigueur dès l'échange des instruments de ratification" (art. $22 \S 1$ ).

72 „Au cas où une des Hautes Parties Contractantes viendrait à considérer que les éléments liés à la conclusion du présent Accord-cadre ont subi des changements tels que des modifications deviennent nécessaires, les deux Parties décideront, d'un commun accord, d'ouvrir des négociations" (art. 22 2). 
mocy i Rozwoju Integralnego w Muyinga; w diecezji Ngozi: Niższe Seminarium w Murek, Biuro Wsparcia dla Rozwoju i Pomocy Społecznej; w diecezji Rutana: Niższe Seminarium w Mika, Organizacja dla Rozwoju i Pomocy Społecznej; w diecezji Ruvigi: Niższe Seminarium w Dutwe, Solidarność dla Promocji Opieki i Rozwoju; 4) Stowarzyszenie Przełożonych Wyższych (Konferencja Przełożonych Wyższych Zakonów Męskich; Unia Przełożonych Wyższych Zakonów Żeńskich); 5) instytuty życia konsekrowanego (58 instytutów męskich i żeńskich); 6) stowarzyszenia wiernych, ruchy Akcji Katolickiej i nowych wspólnot agregowanych przez władzę kościelną ( 8 Stowarzyszeń $)^{73}$.

\section{ZAKOŃCZENIE}

Zaprezentowana umowa ramowa Stolicy Apostolskiej i Republiki Burundi w sprawach wspólnego interesu stanowi właściwe narzędzie służące uregulowaniu wzajemnych stosunków między Kościołem katolickim i wymienionym państwem afrykańskim. Umowa ta postawiła Kościół w pozycji „środkowej” między tradycyjnymi oporem prawa rodowego, laickimi tendencjami kulturowymi oraz umiejętnościami manipulacyjnymi kolejnego rządu z jednej strony, a wolą odnowy w nurcie ewangelicznym pojednania i solidarności, w szczególności etnicznej, $\mathrm{z}$ drugiej strony ${ }^{74}$.

Ta perspektywa społeczna i instytucjonalna, dość złożona, sprawiła, że w negocjowaniu traktatu przyjęto dużą ostrożność, co widać m.in. w regulacji dotyczącej małżeństwa. Niemniej poczynione przez układające się strony uzgodnienia stanowią waży krok w dziele trwającego wciąż zakorzeniania Ewangelii w życiu narodu burundyjskiego. Świadczą o tym m.in. słowa trzeciego akapitu Preambuły, w myśl którego Kościół katolicki ma znaczenie w życiu narodu burundyjskiego, przyczyniając się do jego rozwoju duchowego, moralnego, społecznego, kulturowego i materialnego.

Niemałe znaczenie należy przypisać wyeksponowaniu zasady niezależności, autonomii i suwerenności państwa i Kościoła katolickiego, podobnie jak zasady wolności religijnej, a liczne gwarancje udzielone temuż Kościołowi w urzeczywistnianiu własnej, wrodzonej mu misji wymownie świadczą o jej rozumieniu i poszanowaniu przez Republikę Burundi.

Postanowienie, iż w czterech przypadkach (art. 14, 15, 17, 19) bardziej szczegółowe regulacje staną się przedmiotem rokowań między Rządem Burundi i tam-

\footnotetext{
${ }^{73}$ Accord-Cadre entre le Saint-Siège et la République du Burundi, Annexe.

${ }^{74}$ VECCHI, Il concordato del 2012, s. 585.
} 
tejszą Konferencją Biskupów Katolickich, a w jednym przypadku przez komisję mieszaną (art. 18), zdają się wskazywać na rolę tejże Konferencji w złożonym procesie inkulturacji burundyjskiej.

Czymś znamiennym dla umowy ramowej jest zachowanie w mocy zawartych wcześniej, wyszczególnionych w art. 20 § 2, siedmiu umów między Rządem Burundi i Konferencją Biskupów Katolickich Burundi w zakresie, w którym nie pozostają one w sprzeczności tym, co jest przewidziane w umowie ramowej.

Wyzwanie do inkulturacji wiary w Afryce, tak bliskie Janowi Pawłowi II (odbył tam 42 wizyty apostolskie [na 55 państw], m.in. w Burundi, w latach 1980-2000), opierało się „na zapewnieniu, że wyznawcy Chrystusa przyswoiliby sobie bardziej dogłębnie przesłanie Ewangelii, gdyby pozostali wierni wszystkim autentycznym wartościom afrykańskim"

Należy mieć nadzieję, że umowa ramowa Stolicy Apostolskiej i Republiki Burundi, uchylając przesłonę między Kościołem a kulturą plemienną tego kraju (podobnie jak innych krajów afrykańskich) przyczyni się do pogłębienia przez tamtejszych katolików ewangelicznego przesłania, a tym samym stanie się skutecznym narzędziem inkulturacji na kontynencie afrykańskim.

\section{BIBLIGRAFIA}

\section{ŹRÓDŁA PRAWA}

Sacrosanctum Concilium Oecumenicum Vaticanum II: Constitutio pastoralis de Ecclesia in mundo huius temporis Gaudium et spes (7.12.1965), AAS 58 (1966), s. 1025-1115; tekst polski: SoBóR WATYKAŃSKi II, Konstytucje, dekrety, deklaracje, tekst polski, nowe thumaczenie, Pallottinum, Poznań 2002, s. 526-606.

Testi consultabili, [w:] Codes et lois, red. R. Bellon i P. Delfosse, Bruxelles-Bujumbura: Maison Fedinand Larcier 1970.

IoAnnes Paulus PP. II: Adhortatio apostolica Catechesi tradendae (16.10.1979), AAS 71 (1979), s. $1277-1340$.

IoAnnes Paulus PP. II: Adhortatio apostolica Ecclesia in Africa (14.09.1995), AAS 88 (1996), s. 5-82. Accord-Cadre entre le Saint-Siège et la République du Burundi sur matières d'intérêt commun (6.11.2012), AAS 106 (2014), s. 195-207.

Konkordat między Stolicą Apostolską i Rzecząpospolitą Polską z 28 lipca 1993 roku, Dz. U. z 1998 r. Nr 51, poz. 318.

Constitution du Burundi (18.03.2005), [w:] https://ww.refwordl.org/docid/2c2df0942HTML [dostęp: 21.03.2020].

${ }^{75}$ IoAnnes Paulus PP. II, Adhortatio apostolica Ecclesia in Africa, nr 78; zob. także J.R. MwANIKI, Odrodzenie Afryki podczas pontyfikatu Jana Pawła II, [w:] 40-lecie wyboru Karola Wojtyty na papieża. Czy pontyfikat Jana Pawła II zmienit świat?, red. P. Skibiński, Warszawa: Centrum Myśli Jana Pawła II 2018, s. 128-158. 
Accordo tra la Santa Sede e la Repubblica de Guinea Equatoriale sulle relazioni tra la Chiesa Cattocica e lo Stato - Acordo entre la Repubblica de Guinea Ecuatorial y la Santa Sede sobre las relaciones entre la Iglesia Católica y El Estado (13.10.2012), AAS 105 (2013), s. 987-1000.

Accordo tra la Santa Sede e la Repubblica di Capo Verde sullo statuto giuridico della Chiesa cattolica in Capo Verde - Acordo entre la Santa Sede el la República de Capo Verde relativo ao estatuto jurídico de Igreja católica em Capo Verde (10.06.2013), AAS 106 (2014), s. 220-241.

\section{LITERATURA}

Annuario Pontificio, Città del Vaticano: Libreria Editrice Vaticano 2006.

Budzisz Marian: Burundi, w: Encyklopedia Katolicka, t. II, Lublin: Towarzystwo Naukowe KUL 1976, kol. 1230-1231.

Burundi, [w:] Encyklopedia Gazety Wyborczej, t. III, Kraków [b.w.r.w.]

GóRALSKI Wojciech: Gwarancje wolności religijnej w konkordacie między Stolicą Apostolską i Republiką Zielonego Przylądka, Opolskie Studia Administracyjno-Prawne 13 (2015), nr 4, s. 77-95.

GóRALSKI Wojciech: Wzajemne relacje Kościoła katolickiego i i państwa w konwencji między Stolicą Apostolską i Republiką Gwinei Równikowej, Przegląd Prawa Wyznaniowego 7 (2015), s. 25-40.

Halemba Andrzej: Zagadnienie inkulturacji w Afryce w okresie powstania Orędzia „Africae terrarum” Pawła VI, Śląskie Studia Historyczno-Teologiczne 25-26 (1992-1993), s. 69-98.

IwaKa Kitambala Hilaire: Les doits de l'homme en RD Congo et la geopolitique de l'integration dand les Pays de Grand Lacs. Une étude juridique de la contribution de l'ONU et de l'Eglise, Roma: Pontificia Università Lateranense 2012.

KazINA Ida-Marie: Proposition pour une pastorale familiale au Burundi, Au Coer de l'Afrique 1-2 (2002), s. 36-175.

Mwaniki Joseph R.: Odrodzenie Afryki podczas pontyfikatu Jana Pawła II, [w:] 40-lecie wyboru Karola Wojtyły na papieża. Czy pontyfikat Jana Pawła II zmienił świat?, red. P. Skibiński, Warszawa: Centrum Myśli Jana Pawła II 2018, s. 128-158.

Ndikumasabo Joseph: Paix et justice et éducation à ses valeurs du Burundi à la lumière des messages ponificaux pour la Journée mondiale de la paix, Roma: Università Pontificia Salesiana 2004.

Republika Burundi, [w:] https://encyklopedia.interia.pl/geografia-nauki-pokrewne/panstwa/news-burundi,nId,2010934\#utm_source=paste\&utm_medium=paste\&utm_campaign=other [dostęp: 19.03.2020].

VecChi Fabio: Il concordato del 2012 tra la Santa Sede e la Repubblica del Burundi alla prova di un'inculturazione che precede il dirito alla libertà religiosa, Ius Ecclesiae 30 (2018), nr 2, s. 571-591.

\section{UMOWA RAMOWA MIĘDZY STOLICĄ APOSTOLSKĄ I REPUBLIKĄ BURUNDI W SPRAWACH WSPÓLNEGO INTERESU Z 6 LISTOPADA 2012 ROKU NARZĘDZIEM INKULTURACJI NA KONTYNENCIE AFRYKAŃSKIM}

\section{Streszczenie}

W dość długi już katalog umów zawieranych po Soborze Watykańskim II przez Stolicę Apostolską z państwami afrykańskimi wpisała się umowa ramowa (Accord-cadre) w sprawach wspólnego interesu (sur matières d'intérêt commun) zawarta 6 listopada 2012 r. z Republiką Burundi. Traktat ten, obejmujący preambułę, 22 artykuły oraz aneks, reguluje szeroki wachlarz spraw interesujących obydwie strony. Stanowi znaczący, jak się wydaje, instrument służący wzajemnemu, obustronnie wzbogacającemu dialogowi kultury z wiarą. 
Preambuła umowy, obejmująca siedem akapitów, wskazuje cel, przesłanki i okoliczności jej zawarcia. Uzgodnienia zawarte w Umowie ramowej, zawarte w poszczególnych artykułach, dotyczą następujących spraw: zasady ogólne, sprawowanie kultu Bożego, nominacje kościelne, przestępstwa duchownych i osób zakonnych oraz sekrety: spowiedzi i zawodowy, dobra materialne kościelnych osób prawnych oraz duchownych, budownictwo sakralne i kościelne, posługiwanie się przez Kościół środkami przekazu, małżeństwo, zrzeszanie się wiernych, prowadzenie przez Kościół placówek oświatowych i wychowawczych, prowadzenie przez Kościół instytucji dobroczynnych, udział finansowy Państwa w działalności Kościoła na rzecz narodu, opieka duszpasterska nad zaangażowanymi w siłach zbrojnych i bezpieczeństwa oraz nad przebywającymi w zakładach i instytutach zamkniętych, postanowienia końcowe.

Należy mieć nadzieję, że umowa Stolicy Apostolskiej i Republiki Burundi, uchylając rozdźwięk między Kościołem a kulturą plemienną tego kraju, stanie się - w jakiejś mierze - skutecznym narzędziem inkulturacji na kontynencie afrykańskim.

Słowa kluczowe: umowa ramowa; Burundi; Stolica Apostolska; inkulturacja

\section{FRAMEWORK AGREEMENT BETWEEN THE HOLY SEE AND THE REPUBLIC OF BURUNDI OF 6 NOVEMBER 2012 ON MUTUAL INTEREST AS A TOOL OF INCULTURATION ON THE AFRICAN CONTINENT}

\section{Sum mary}

Among quite a long catalogue of agreements concluded by the Holy See with African states after the Second Vatican Council there is the framework agreement (Accord-cadre) on mutual interest (sur matières d'intérêt commun) concluded on 6 November 2012 with the Republic of Burundi. The treatise consisting of the preamble, 22 articles and the annex regulates a wide range of matters of interest to both parties. Apparently it is a considerable instrument aimed at mutual dialogue of the culture and faith, which enriches both parties.

The preamble of the agreement composed of seven paragraphs features the objective, rationale and circumstances of its conclusion. The arrangements included in particular articles of the Framework Agreement deal with the following issues: general matters, exercise of the God's cult, church nominations, crimes committed by the clergy and members of religious orders, the secret of confession and professional secret, material goods of ecclesiastical legal persons and the clergy, sacral and church buildings, the use of the mass media by the Church, marriage, congregating of the faithful, running educational and fostering facilities by the Church, running charitable institutions by Church, the state's financial contribution in the activities pursued by the Church for the nation, ministerial care over persons engaged in armed and security forces and over persons staying in closed facilities and institutes, final provisions.

It should be hoped that while bridging the differences between the Church and country's tribal culture the agreement of the Holy See and the Republic of Burundi will become to some extent and effective tool of inculturation on the African continent.

Key words: framework agreement; Burundi; the Holy See; inculturation 